\title{
Thalassemia Patients from Baluchistan in Pakistan Are Infected with Multiple Hepatitis B or C Virus Strains
}

\author{
Sheikh Ahmed, ${ }^{1,2,3}$ Muhammad Ayub, ${ }^{1}$ Muhammad Naeem, ${ }^{4}$ Faisal Hayat Nazir,${ }^{5}$ Abrar Hussain, ${ }^{6}$ Daud Ghilzai, ${ }^{3}$ Lars O. Magnius, ${ }^{7}$ \\ Ashif Sajjad, ${ }^{1}$ and Heléne Norder ${ }^{2,8 *}$ \\ ${ }^{1}$ Institute of Biochemistry, University of Baluchistan Quetta, Quetta, Pakistan; ${ }^{2}$ Department of Infectious Diseases/Virology, Institute of \\ Biomedicine, Sahlgrenska Academy, University of Gothenburg, Gothenburg, Sweden; ${ }^{3}$ BUMHS Bolan University of Medical and Health Sciences \\ Quetta, Quetta, Pakistan; ${ }^{4} \mathrm{MSPH}$ Shaheed Zulfikar Ali Bhutto Institute of Science and Technology, Karachi, Pakistan; ${ }^{5}$ Department of Psychiatry \\ and Neurochemistry, Institute of Neuroscience and Physiology, Sahlgrenska Academy, University of Gothenburg, Gothenburg, Sweden; \\ ${ }^{6}$ Baluchistan University of Information Technology, Engineering Management Science, Quetta, Pakistan; ${ }^{7}$ Ulf Lundahls Foundation, Stockholm, \\ Sweden; ${ }^{8}$ Department of Clinical Microbiology, Sahlgrenska University Hospital, Gothenburg, Sweden
}

\begin{abstract}
There are an estimated 2,000 children with $\beta$-thalassemia in the province Baluchistan of Pakistan. These children are at high risk of acquiring transfusion-transmitted infections (TTls) due to their need of regular blood transfusions for survival. Therefore, we investigated the frequencies of TTls among these multi-transfused patients in a region where the WHO guidelines for blood safety are not always followed. Sera from 400 children (mean age $7.7 \pm 4.70$ years) treated at two thalassemia centers in Baluchistan were investigated for TTls. Eleven (2.8\%) were hepatitis B surface antigen positive, and $72(18.3 \%)$ had anti-hepatitis $\mathrm{C}$ virus (HCV), two of which were infected with both viruses. Only $22 \%$ of the children had been reached by the program for universal hepatitis B virus (HBV) vaccination which started in 2004. Half $(51 \%)$ of the HCV infected had also been HBV infected. The HBV-and HCV-infected patients were older and had received more blood transfusions than the uninfected patients $(P<0.001)$. Molecular characterization of the viral strains revealed the presence of several genetically different strains in at least three HBV-and seven HCV-infected children. This is the first study to demonstrate infections with multiple HBV or HCV strains simultaneously infecting thalassemia patients. These may become the source for new emerging recombinant viruses of unknown virulence. The high prevalence of anti-HCV-positive children, and the presence of HBV infections among children who should have been vaccinated, highlights an urgent need for improvements of blood safety in this region of Pakistan.
\end{abstract}

\section{INTRODUCTION}

There are five provinces in Pakistan, of which Baluchistan is the largest, but only 13 million of the country's total 208 million inhabitants live in this province. The capital Quetta in the northern part has one million inhabitants (Figure 1). Baluchistan is a poor province and has the lowest human development index in the country ${ }^{1}$; in 2018 , it was 0.477 , whereas it was 0.678 for Islamabad. Vaccination against hepatitis $B$ virus (HBV) as part of the Expanded Program on Immunization (EPI) was launched nationwide in 2004. This was financed by a grant received from the Global Alliance for Vaccines and Immunization in 2001-2002. ${ }^{2}$ There have been failures in the EPI for preventing the spread of infections of public concern in Baluchistan, and poliomyelitis is still endemic in the area with 12 cases reported in $2019 .^{3}$

Thalassemia is one of the most common genetic disorders and affects $1.5 \%$ of the world population. ${ }^{4} \beta$ thalassemia is caused by mutations in the hemoglobulin subunit beta gene on chromosome $11^{5}$ and is inherited in an autosomal, recessive trait. ${ }^{5}$ The disorder is associated with populations originating from the Mediterranean, Middle East, and Indian subcontinent, but is now widespread also in other areas. ${ }^{6}$ The severity of the disease depends on the nature of the mutation and on the presence of mutations in both alleles (thalassemia major as $\beta$-thalassemia) or in one allele (thalassemia minor). $\beta$-thalassemia is common in Pakistan and affects $5-7 \%$ of its population. ${ }^{7}$ Regular blood transfusion is required to reduce anemia in these patients. ${ }^{8}$ Because this remains the only treatment, these patients are at high risk for developing liver cirrhosis or cardiac

*Address correspondence to Heléne Norder, Gothenburg University, Guldhedsgatan 10B, 41346, Gothenburg, Sweden. E-mail: helene.norder @gu.se complications and often die because of iron overload at the age of 30 years or earlier. ${ }^{9}$

Viral hepatitis infections are considered among the top eight causes of deaths, with approximately 1.34 million yearly deaths globally. ${ }^{10}$ It has been estimated that 257 million persons are chronically infected with HBV and 71 million with hepatitis $\mathrm{C}$ virus (HCV). ${ }^{10}$ The diseases are called silent killer because many patients remain undiagnosed and untreated for many years before their health complications arise. To reduce the negative impact of hepatitis on global health, the World Health Assembly adopted the Global Health Sector Strategy on viral hepatitis to eliminate hepatitis by $2030 .{ }^{11}$ In Pakistan, almost 12 million people are suffering from $\mathrm{HBV}$ or $\mathrm{HCV}$, with a yearly incidence of about 200,000 new cases. ${ }^{12}$ In the general population, the prevalence of $\mathrm{HCV}$ is almost $5 \%$ and of $\mathrm{HBV}$ is $3-5 \% .^{13-16}$ There are probably more infected persons because these infections are blood transmitted, and blood safety is not well handled in all regions of Pakistan. In addition, many of healthcare workers may be infected without being aware of it, and there is no general testing of health personnel. ${ }^{12,17,18}$

Safe blood is not always readily available, and consequently, $\beta$-thalassemia patients often acquire transfusion-transmitted infections (TTls), and many Pakistani patients have been infected. ${ }^{19,20}$ The reasons for the high number of TTls include practices and measures of blood supply below the standard recommended by the $\mathrm{WHO}^{21}$ and other nosocomial transmissions due to lack of resources and poorly trained staff. ${ }^{22}$ In 2005 , the prevalence of hepatitis B was $4 \%$ in the general population and less than $2 \%$ in children in Pakistan, ${ }^{23}$ whereas it was twice as high in $\beta$-thalassemia patients. ${ }^{24}$ For HCV infections, the prevalence is around $6 \%$ in the general population, ${ }^{25}$ but $20-58 \%$ in $\beta$-thalassemia patients. Transfusion-transmitted infections are also common among thalassemia patients in India, Iran, Iraq, and Pakistan. ${ }^{26-28}$ 


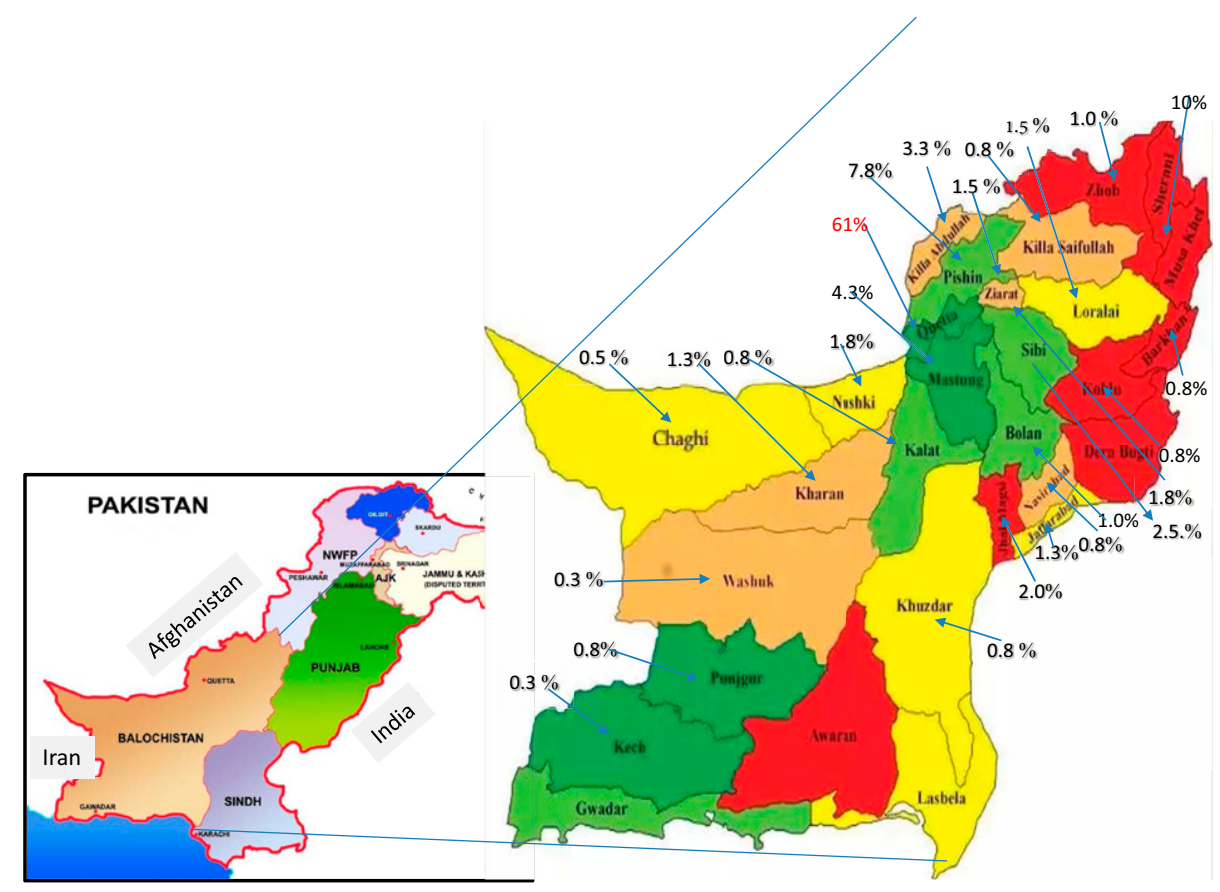

FIGURE 1. Map of Pakistan with the Baluchistan Province enlarged. The figures indicate the origin of the 400 children with $\beta$-thalassemia included in the study. This figure appears in color at www.ajtmh.org.

An earlier study of TTls in multiply transfused patients with thalassemia majorly revealed high incidences of HCV and HBV in Rawalpindi, Islamabad, and Karachi, ${ }^{29}$ but studies have so far not been conducted on these patients in Baluchistan. Therefore, the aim of this study was to investigate the prevalence of TTIs in multi-transfused $\beta$-thalassemia patients treated in this province.

\section{MATERIALS AND METHODS}

Patients. The study was conducted at the two thalassemia centers in Baluchistan, the Bolan medical college hospital $(\mathrm{BMCH})$ and the Civil Hospital Quetta $(\mathrm{CHQ})$, which provide screened blood and medical care for $\beta$-thalassemia patients. In total, 400 of 2,000 patients with confirmed $\beta$-thalassemia were investigated: 239 patients were from $\mathrm{BMCH}$ and 161 from CHQ. Blood samples were collected from March 2017 until June 2018 at the Department of Pathology at the BMCH.

$\beta$-thalassemia was diagnosed by hemoglobin $(\mathrm{Hb})$ electrophoresis. A questionnaire was used to record clinical data and family history of the patients. The records included age, gender, ethnic origin, and family history (parent consanguinity and number of individuals with $\beta$-thalassemia in the household family). The total number of transfusions was estimated by the parents, who also informed about the age of the child at diagnosis. Information was also obtained regarding previous or present jaundice, and splenectomy or hepatomegaly, and previous vaccination against HBV (Supplemental Table S1).

Ethical approval. Ethical approval was obtained from the research committee of the University of Baluchistan in Quetta (Reg No UOB/06/2020). Informed consent was obtained from all patients and/or their guardians/parents before sampling.

Serological analyses. Hemoglobin was analyzed for in an XS-500i Sysmex analyzer (GmbH, Norderstedt, Germany).
Serum ferritin was quantified by Cobas Integra 400 plus (Roche, Basel, Switzerland), and alanine amionotransferase test (ALT) by Selecta Pro XL (ELITech Group, Puteaux, France).

All sera were tested for HBV surface antigen (HBsAg), antibodies against HCV (anti-HCV), antibodies against hepatitis delta virus (anti-HDV), antibodies against HIV (anti-HIV), and antibodies against cytomegalovirus (anti-CMV) by ELISA (Dia 710 Diamate; Bio-technologies, Hertfordshire, England) at the $\mathrm{BMCH}$. Antibodies against HBV core antigen (anti-HBc), against hepatitis $B$ surface antigen (anti-HBs), hepatitis $B$ e antigen ( $\mathrm{HBeAg})$, antibodies against $\mathrm{HBeAg}$ (anti-HBe), and HCV core antigen were analyzed at the Clinical Microbiology Laboratory (CML) at Sahlgrenska University Hospital in Gothenburg, Sweden. The analyses were performed by chemiluminescent microparticle immunoassay from Abbott Laboratories (Abbott Park, IL) on ARCHITECT i2000SR platform. For HCV core antigen, samples with $<3 \mathrm{fmol} / \mathrm{L}$ were considered negative, those with 3-10 fmol/L boarder line, and those with $>10 \mathrm{fmol} / \mathrm{L}$ were considered positive.

PCR amplification and sequencing. Nucleic acids (NA) in $200 \mu \mathrm{L}$ of serum reactive for either anti-HCV or HBsAg were extracted on NucliSENS EasyMAG automated system (BioMerieux, Marcy l'Etoile, France) at CML. The extracted NAs were stored at $-80^{\circ} \mathrm{C}$ until further analyzed. Hepatitis $\mathrm{C}$ virus RNA detection, cDNA synthesis, PCR, purification of amplified PCR products and cycle sequencing were performed as described previously. ${ }^{30}$ The sequences obtained are deposited in GenBank with accession numbers MW234350-MW234406.

Phylogenetic analysis. The HBV and HCV sequences were analyzed in the SeqMan Pro 13 program in the DNAStar Program package version 10.1.2 (DNAStar Inc, Madison, WI). The HBV S-gene, the HCV core, and the NS5B sequences were aligned with corresponding sequences from GenBank. Evolutionary distances were calculated using the HasegawaKishino-Yano algorithm with gamma correction in the 
DNADIST program in the PHYLIP package version 3.65 (University of Washington, Seattle, WA). ${ }^{31}$

Statistical analysis. For means and corresponding SDs (mean $\pm \mathrm{SD}$ ), range is presented when proportions were expressed by percentages. Prevalence of HBV and HCV infections were compared with regard to age, number of transfusions received, and serum ferritin levels between $\mathrm{HBsAg}$ and anti-HCV reactive and nonreactive participants using Fisher's exact test. All statistical analyses were carried out using SPSS software version 24.0 (IBM, Chicago, IL), and $P$-values $\leq 0.05$ were considered statistically significant.

\section{RESULTS}

Demographical data of the patients. The mean age of the patients was $7.70 \pm 4.70$ years (range $2-27$ years). One patient was older than 25 years. There were slightly more boys than girls (228 versus 172; Table 1). Most patients (244; 61\%) were from Quetta, since many families had moved there due to poor blood facilities in other districts of the province. Because of poor availability of blood, families pay relatives or students to donate blood at a nearby pharmacy. This blood, which is often unscreened for TTIs, is then transfused to the children at their homes by the parents. Consanguineous marriages are common in Baluchistan. In this study, there were 300 (75\%) interfamily marriages, and $71 \%$ of the families had several members with thalassemia.

Clinical data. The average age at diagnosis of $\beta$-thalassemia was 5 months, and for the first transfusion it was 6 months. To reach $\mathrm{Hb}$ levels of $\geq 9 \mathrm{~g} / 100 \mathrm{~mL}, 37 \%$ of the patients had to receive two to four blood units monthly, the others received one blood unit every month (Table 1).

ALT and serum ferritin values were related to the number of blood units the patients had received during their lifetime (Table 2). For all children the serum ferritin levels were more than four times the upper normal limit, and $70 \%$ had elevated ALT levels (Supplemental Table S2).

Transfusion transmitted infections. At inclusion, 11 patients were HBsAg positive and 73 had anti-HCV (Table 1). Two patients, aged 10 and 18 years, were infected with both viruses. One 22-year-old patient was infected with HDV, and another 16-year-old with HIV. The number of TTIs increased with the number of blood transfusions received (Table 2). Children with TTIs had more often splenectomy than noninfected children $(P<0.0001$; Supplemental Table S2).

Despite the EPI, in which $87 \%$ of the children should have been included, only $22 \%$ had been vaccinated against hepatitis $B$ according to their parents. To confirm this, anti-HBc and anti-HBs were analyzed in available sera from 64 of the $\mathrm{HCV}$ infected patients used for HCV typing. Four of seven children lacking these markers were born after 2004. Anti-HBs without anti-HBc, indicating vaccination, were found in 12 of 38 children born after 2004, and in five of 26 older patients. Evidence of past HBV infection with high levels of both anti$\mathrm{HBc}$ and anti-HBs was found for 23 patients; six of them were vaccinated according to their parents. Reactivity was found only for anti-HBc in 11 patients.

Hepatitis B. The HBV-infected patients were older than uninfected, 13.2 (range 6-22 years) versus 6 years (range 1-17 years; $P=0.001$ ), and had received more transfusions (mean 264 versus 96; Supplemental Table S2). They had higher levels

TABLE 1

Demographic data and prevalence of transfusion-transmitted infections in the 400 children with $\beta$-thalassemia

\begin{tabular}{|c|c|c|c|c|c|c|c|}
\hline Variable & $n=400(\%)$ & $\begin{array}{c}\text { Hepatitis B virus } \\
\text { positive, } n=11 \text { (\%) }\end{array}$ & $P$-value & $\begin{array}{c}\text { Hepatitis } C \text { virus } \\
\text { positive, } n=72(\%)\end{array}$ & $P$-value & $\begin{array}{c}\text { CMV positive, } \\
n=349(\%)\end{array}$ & $P$-value \\
\hline Age-group (years) & & & $<0.001$ & & $<0.001$ & & $<0.001$ \\
\hline $0-5$ & $124(31)$ & $0(0.0)$ & & $1(0.8)$ & & $93(75)$ & \\
\hline $5-14$ & $236(59)$ & $6(2.4)$ & & 45 (19) & & $217(92)$ & \\
\hline$\geq 15$ & 40 (10) & $5(12)$ & & $27(68)$ & & 39 (98) & \\
\hline Gender & & & 0.541 & & 0.873 & & 0.983 \\
\hline Male & $228(57)$ & $5(2.2)$ & & $41(18)$ & & $199(87)$ & \\
\hline Female & $172(43)$ & $6(3.5)$ & & 32 (19) & & $150(87)$ & \\
\hline Number of transfusions & & & $<0.01$ & & $<0.001$ & & $<0.001$ \\
\hline$<50$ & $128(32.0)$ & 0 & & 1 & & 97 & \\
\hline $50-199$ & 161 (40.3) & 4 & & 25 & & 145 & \\
\hline 200-349 & 78 (19.3) & 4 & & 23 & & 74 & \\
\hline$\geq 350$ & $33(8.3)$ & 3 & & 24 & & 30 & \\
\hline Transfusion frequency every 4 weeks & & & - & & & & - \\
\hline Once & $252(63)$ & 4 & & 18 & & 205 & \\
\hline Twice & $114(28)$ & 4 & & 37 & & 11 & \\
\hline Three times & $33(8.3)$ & 3 & & 18 & & 33 & \\
\hline Four times & $1(0.3)$ & 0 & & 0 & & 1 & \\
\hline Splenectomy & $91(22.8)$ & $5(5.5)$ & & $37(41.7)$ & $<0.001$ & & \\
\hline Hepatitis $B$ vaccination & & & - & & & & - \\
\hline \multicolumn{8}{|l|}{ According to parents } \\
\hline Vaccinated & $97(24)$ & $4(36)$ & & $19(26)$ & & $87(25)$ & \\
\hline Not vaccinated & $213(53)$ & $6(54)$ & & $47(64)$ & & $182(52)$ & \\
\hline Unknown & $90(22)$ & $1(10)$ & & $7(10)$ & & $80(23)$ & \\
\hline Patients born after 2004 & 350 & 4 & - & 43 & - & 301 & - \\
\hline Vaccinated & $79(22)$ & 2 & & 9 & & 70 & \\
\hline Not vaccinated & $188(54)$ & 2 & & 30 & & 158 & \\
\hline Unknown & $83(24)$ & 0 & & 4 & & 73 & \\
\hline Treatment center & & & 0.032 & & & & 0.653 \\
\hline Civil hospital & $239(59.8)$ & $3(5)$ & & $35(22)$ & 0.138 & $139(86)$ & \\
\hline Bolan medical complex & $161(40.2)$ & $8(1.3)$ & & $38(16)$ & & $210(88)$ & \\
\hline
\end{tabular}

Bold values denote statistical significance values. 
TABLE 2

Number of transfusions in relation to age and hepatitis B virus and HCV infections at the end of the study period among the 400 children with $\beta$-thalassemia

\begin{tabular}{|c|c|c|c|c|c|c|}
\hline Number of transfusions & Number of patients & $\begin{array}{l}\text { Age-group } \\
\text { (years) }\end{array}$ & $\begin{array}{l}\text { Number HBV surface } \\
\text { antigen positive }\end{array}$ & $\begin{array}{l}\text { Number anti- } \\
\text { HCV positive }\end{array}$ & $\begin{array}{l}\text { Serum ferritin }(\mathrm{ng} / \mathrm{mL}) \\
\text { (normal range } 12-300)\end{array}$ & $\begin{array}{l}\mathrm{ALT}(\mathrm{IU} / \mathrm{L}) \text { (normal } \\
\text { range } 7-45 \text { ) }\end{array}$ \\
\hline \multirow[t]{3}{*}{$<50$} & 128 & $<5$ & 0 & 1 & $1,190 \pm 868$ & - \\
\hline & & $5-14$ & 0 & - & - & $36.1 \pm 12.3$ \\
\hline & & $\geq 15$ & 0 & - & - & - \\
\hline Subtotal & & & 0 & $1(0.8 \%)$ & - & - \\
\hline \multirow[t]{3}{*}{$50-199$} & 161 & $<5$ & 0 & 0 & $3,381 \pm 1,807$ & - \\
\hline & & $5-14$ & 4 & 24 & - & $53.8 \pm 18.5$ \\
\hline & & $\geq 15$ & 0 & 1 & - & - \\
\hline Subtotal & & & $4(2.5 \%)$ & $25(15.5 \%)$ & - & - \\
\hline \multirow[t]{3}{*}{$200-349$} & 78 & $<5$ & 0 & - & - & - \\
\hline & & $5-14$ & 2 & 16 & $5,278 \pm 2,338$ & $73.8 \pm 19.1$ \\
\hline & & $\geq 15$ & 2 & 7 & - & - \\
\hline Subtotal & & & $4(5.1 \%)$ & $23(29.5 \%)$ & - & - \\
\hline$>350$ & 33 & $\geq 15$ & $3(9 \%)$ & $24(72.7 \%)$ & $6,284 \pm 2,293$ & $92.7 \pm 23.7$ \\
\hline Total & 400 & & $11(2.8 \%)$ & $73(18.2 \%)$ & - & - \\
\hline
\end{tabular}

of serum ferritin $(4,559$ versus $2,769 \mathrm{mg} / \mathrm{mL})$ and ALT $(85$ versus $47 \mathrm{IU} / \mathrm{mL})$ than the noninfected $(P<0.001)$. Three of the HBsAg-positive children had HBeAg, and the other eight had anti-HBe. Hepatitis B virus DNA could be amplified by PCR in sera from eight of the $11 \mathrm{HBsAg-positive} \mathrm{patients.} \mathrm{The} \mathrm{S-gene}$ could be sequenced in six samples, three each from patients with $\mathrm{HBeAg}$ and anti-HBe. The sequences were ambiguous for the other two samples, probably because of the presence of several strains. The three children with anti-HBe were infected with at least two different HBV strains, whereas those with $\mathrm{HBeAg}$ were infected with one genotype $\mathrm{D}$ strain each (Supplemental Table S3). Two of the multiply infected had different genotype $D$ strains, one had both a genotype $D$ and a genotype A strain (Table 3, Figure 2). The multiplicity of strains could be revealed because of varying reactivity by the sequencing primers. All children were infected with unique strains, a repeatedly consistent finding. Five strains were divergent from reported genotype $D$ strains and were not similar to the HBV AVD and C/D recombinants described from India. ${ }^{32,33}$

Hepatitis C. The risk of HCV infection was higher than that of HBV when considering the number of transfusions received, with a risk ratio of $34(P<0.0001$; Table 1$)$. Patients with anti-HCV were 13.2 years (range 4-27 years) older than the noninfected patients $(P<0.001)$. They also had higher levels of serum ferritin $(5,233$ versus $2,769 \mathrm{mg} / \mathrm{mL})$ and ALT (86 versus $47 \mathrm{lU} / \mathrm{mL}$ ) than the noninfected $(P<0.001)$.

Sera were available for HCV core antigen analysis for 44 anti-HCV-positive patients. Hepatitis C virus RNA was detected in 19 of 33 patients with high or intermediate HCV core antigen and in one of the 11 patients negative for this antigen. The core and/or NS5B regions could be amplified in 46 of the 73 anti-HCV-positive patients. The strains in 16 patients were difficult to type because of the presence of multiple strains. Genotype 3a strains were identified in 14 children, 3b in three, $2 b$ in five, and $1 b$ in one child. Some sequencing primers amplified only one of several strains in a sample. Multiple strains of subtypes $3 a, 3 b$, and $2 b$ could thereby be identified in at least seven children (Table 3, Supplemental Table S4). The samples with multiple strains were genetically divergent from each other as is shown for the $3 a$ strains based on the core region in Figure 3 , and for the NS5B region in Supplemental Figure S1.

\section{DISCUSSION}

A high prevalence of TTls was found in children with $\beta$ thalassemia in Baluchistan. The number of HBV- or HCVinfected patients increased with age and number of blood transfusions received. High incidence of $\mathrm{HBV}$ or $\mathrm{HCV}$ infections in children with $\beta$-thalassemia has also been described from other regions of Pakistan. ${ }^{29,34-36}$ Many of the children in this study were transfused with unscreened blood because several blood banks and pharmacies in Baluchistan have not implemented infection control measures and lack methods for blood screening, and there are many paid donors in Pakistan.

Several children were infected with more than one HBV or HCV strain. The number of infecting strains and multiple

TABLE 3

Genotypes and subtypes of sequenced HBV and HCV strains

\begin{tabular}{|c|c|c|c|c|c|c|c|c|c|}
\hline \multirow[b]{2}{*}{ Infecting virus } & \multirow[b]{2}{*}{$N$ infected } & \multirow[b]{2}{*}{$N$ sequenced } & \multicolumn{2}{|c|}{ HBV genotype } & \multicolumn{4}{|c|}{ HCV subtype } & \multirow[b]{2}{*}{ Multiply infected } \\
\hline & & & A & $\mathrm{D}$ & $1 b$ & $2 b$ & $3 a$ & $3 b$ & \\
\hline HBV & 11 & 6 & 0 & 3 & & & & & $3^{*}$ \\
\hline $\mathrm{HCV}$ region sequenced & 73 & & & & & & & & \\
\hline NS5B & & 14 & & & 0 & 5 & 6 & 2 & 0 \\
\hline Core & & 9 & & & 1 & 0 & 6 & 1 & 0 \\
\hline Both regions & & 7 & & & 0 & 0 & 1 & 0 & $7 \dagger$ \\
\hline Subtotal & & 30 & & & 1 & 5 & 13 & 3 & 8 \\
\hline Total & $82 \ddagger$ & 36 & 0 & 3 & 1 & 5 & 13 & 3 & 11 \\
\hline
\end{tabular}

* Two children had two different genotype $D$ strains, one child had genotype $A$ and genotype $D$ strains.

$\dagger$ Two children were infected with two $3 a$ strains, three children were infected with one $3 \mathrm{a}$ and one $3 \mathrm{~b}$ strain, and two children were infected with one $2 \mathrm{~b}$ and one $3 \mathrm{a}$ strain.

$\ddagger$ Two children were infected with both HBV and HCV. 


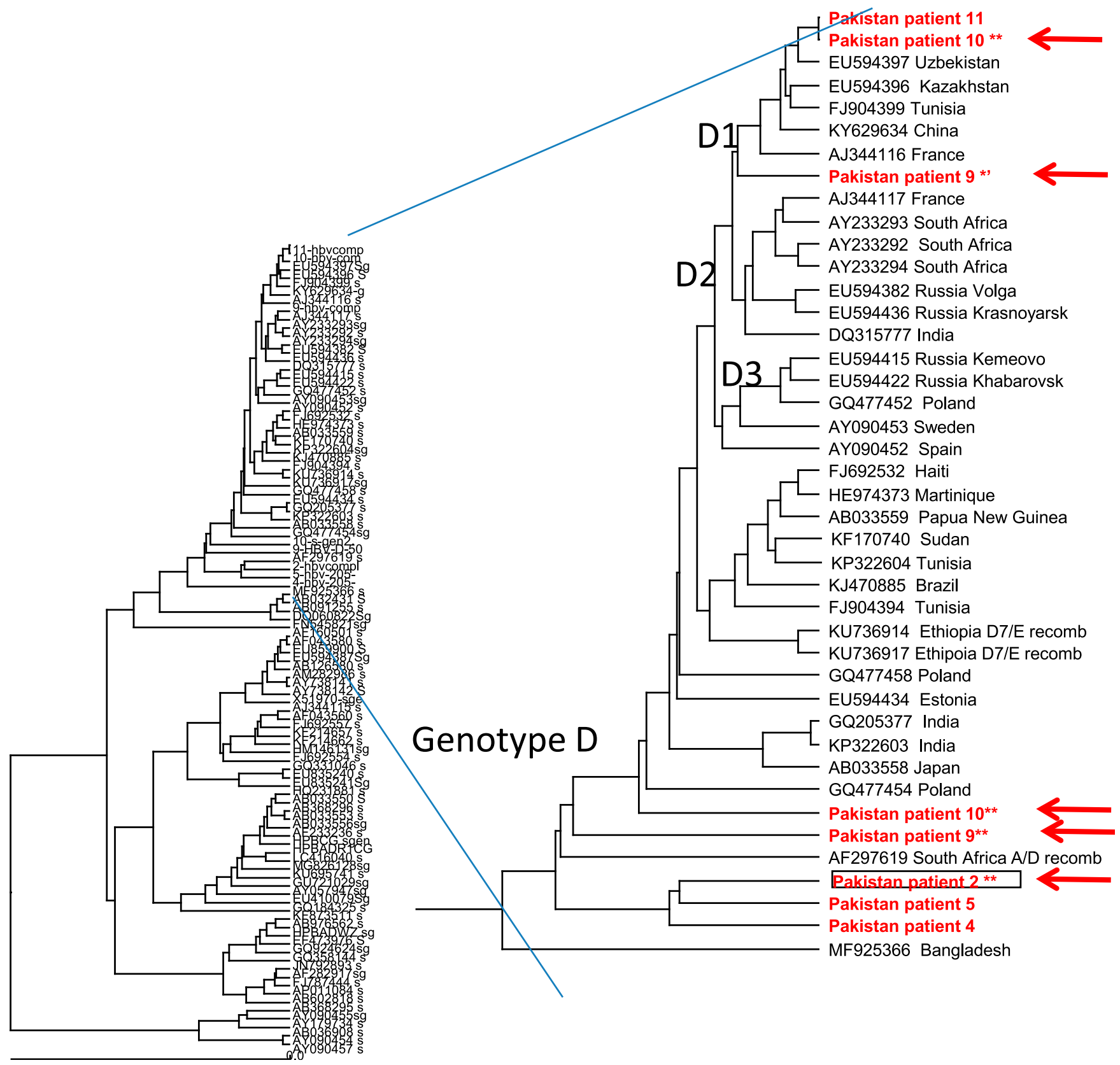

FIGURE 2. Hepatitis B virus (HBV) strains in a phylogenetic tree based on the complete S gene. The strains from this study are marked with red. The strains from children infected with multiple strains are indicated with arrows. The strain indicated with arrow and box is from a child infected with HBV genotype $A$ and $D$ strains. This figure appears in color at www.ajtmh.org.

infected patients may be even higher because some of the strains were only identified because of variations in sensitivity of the sequencing primers. Next-generation sequencing would be needed to determine the exact number of strains in the sera. Multiple infections may be the source for recombinants as shown for HBV in Northern India. ${ }^{32,33}$ The prevalence of hepatitis $C$ in the children with $\beta$-thalassemia was nearly as high as in first-time blood donors in Quetta, ${ }^{37}$ and is the second highest reported prevalence worldwide. ${ }^{38}$ The prevalence of $\mathrm{HBV}$ and $\mathrm{HCV}$ among the patients in this study was equal or somewhat lower than that described from other patients with $\beta$-thalassemia in Pakistan. ${ }^{34,39}$ In the current study, only one patient was positive for HIV. This is in accordance with other studies on HIV in this patient group in Pakistan ${ }^{40}$ and indicates that luckily, for the time being, that HIV infection is not a health burden for thalassemia patients in Pakistan. This may be due to somewhat low prevalence rate of HIV infections in Pakistan. ${ }^{41}$

Because the efficient direct-acting antiviral drugs against HCV now are available in Pakistan, ${ }^{42} \beta$-thalassemia patients need to be treated. However, possible new recombinants may influence on this treatment and need to be monitored. For both $\mathrm{HBV}$ and HCV, the phylogenetic analyses of the sequences showed the presence of several genetically divergent strains. This may either be due to sequencing bias, if multiple strains were present in the samples, or that new divergent strains 


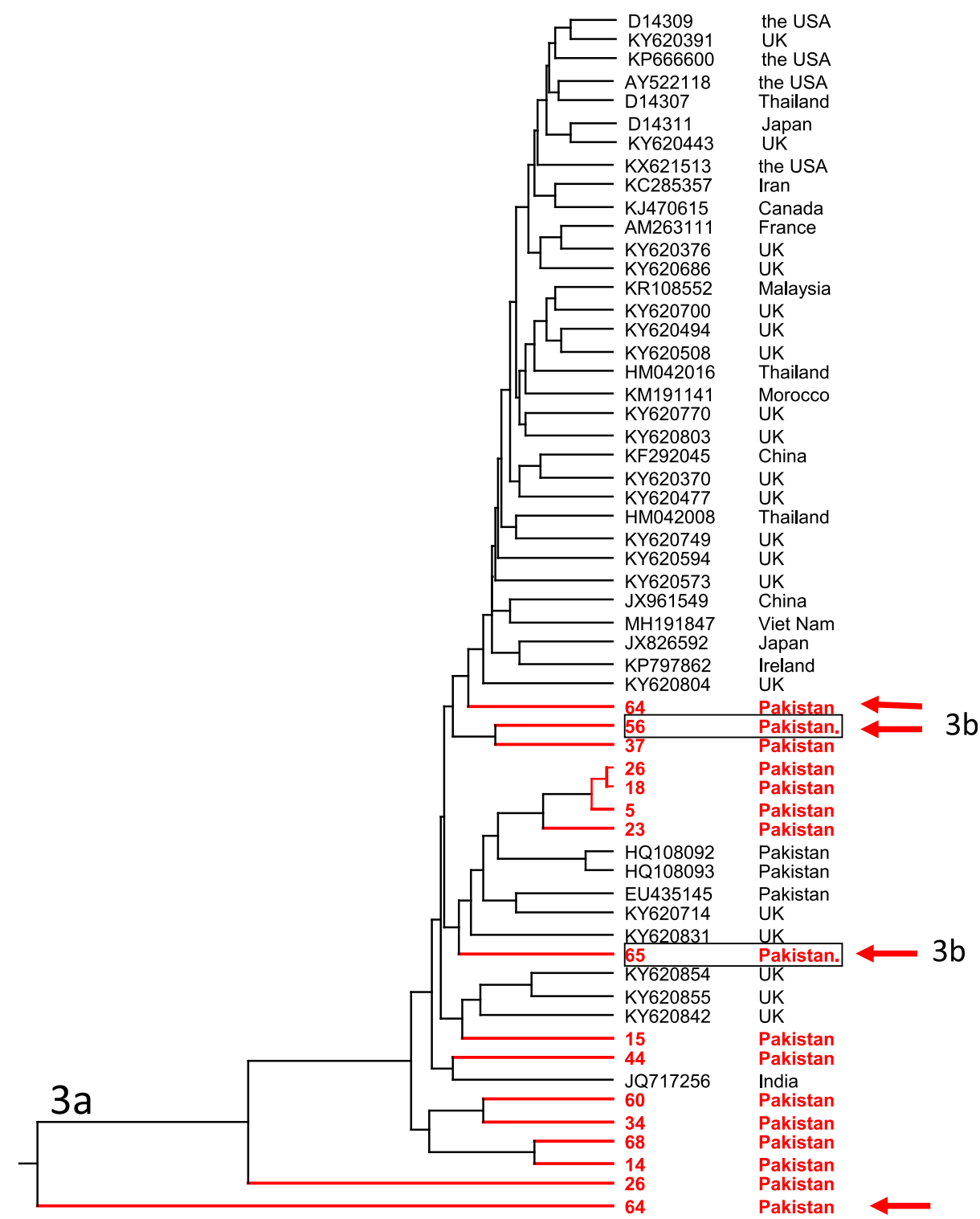

FIGURE 3. Branch of hepatitis C virus (HCV) subtype 3a strains based on partial core region. The strains from this study are marked with red. The strains from children infected with multiple strains are indicated with arrows. The strains indicated with arrows and boxed are from children also infected with subtype $3 b$ strains. This figure appears in color at www.ajtmh.org.

have evolved. The virulence and spread of these viral strains is unknown, and needs further investigation.

Thalassemia is presumably the most common fatal genetic disorder in Pakistan with 5,000-9,000 children born with this blood disorder yearly. ${ }^{7}$ Despite this high prevalence, there is a low awareness regarding $\beta$-thalassemia in the general population. In a study from Karachi, persons were interviewed regarding their knowledge on thalassemia. ${ }^{43}$ Most did not know that it is a genetic disorder which causes a lifelong burden for the affected individuals ${ }^{43}$ and low quality of life. ${ }^{44,45}$ With modern treatments, as iron chelation therapy, and advances in the knowledge of the disorder, the mortality related to thalassemia has been reduced significantly worldwide. These treatments are, however, not affordable for many families in Baluchistan. The number of newborns with $\beta$-thalassemia is declining in Western countries because of the introduction of screening programs. Such programs and education regarding the cause of the disorder is needed also for Pakistan as has been proposed for India. ${ }^{46}$ There is also an urgent need for improvement of blood safety in all regions of Pakistan, both with regard to donor selection and screening methods for TTIs. Improvement of blood and injection safety and interventions for wellfunctioning immunization are strongly needed, especially in Baluchistan.

Received June 26, 2020. Accepted for publication December 9, 2020. Published online February 1, 2021.

Note: Supplemental tables and figure appear at www.ajtmh.org.

Financial support: The Higher Education Commission in Pakistan funded the subsidence of Sheikh Ahmed in Sweden and awarded him a scholarship for bench fee and education in molecular epidemiology at the University of Gothenburg.

Authors' addresses: Sheikh Ahmed, Muhammad Ayub, and Ashif Sajjad, Institute of Biochemistry, University of Baluchistan Quetta, Quetta, Pakistan, E-mails: sheikhzahid2001@gmail.com, ayub_ 
2004@hotmail.com, and ashifsajjad@hotmail.com. Muhammad Naeem, MSPH Shaheed Zulfikar Ali Bhutto Institute of Science and Technology, Karachi, Pakistan, E-mail: z.naeem105835@gmail.com. Faisal Hayat Nazir, Department of Psychiatry and Neurochemistry, Institute of Neuroscience and Physiology, Sahlgrenska Academy, University of Gothenburg, Gothenburg, Sweden, E-mail: faysalkhan86@yahoo.com. Abrar Hussain, Baluchistan University of Information Technology, Engineering Management Science, Baluchistan, Pakistan, E-mail: abrarhussain857@yahoo.com. Daud Ghilzai, BUMHS Bolan University of Medical \& Health Sciences Quetta, Pakistan, E-mail: daudghilzai@gmail.com. Lars O. Magnius, Ulf Lundahls Foundation, Stockholm, Sweden, E-mail: lars.magnius@ gmail.com. Heléne Norder, Department of Infectious Diseases/ Virology, Institute of Biomedicine, Sahlgrenska Academy, University of Gothenburg, Gothenburg, Sweden, E-mail: helene.norder@gu.se.

This is an open-access article distributed under the terms of the Creative Commons Attribution (CC-BY) License, which permits unrestricted use, distribution, and reproduction in any medium, provided the original author and source are credited.

\section{REFERENCES}

1. United Nation, 2020. Human Development Report 2019 Overview. United Nations Development Programme, 22-25.

2. Ministry of Health, 2002. Annual Report, Director General Health 2001-2001. Government of Pakistan.

3. Endpolio, 2019. Pakistan Polio Cases District Wise 2019. Available at: https://www.endpolio.com.pk/polioin-pakistan/polio-casesdistrict-wise-2019. Accessed September 1, 2020.

4. Colah R, Gorakshakar A, Nadkarni A, 2010. Global burden, distribution and prevention of $\beta$-thalassemias and hemoglobin $\mathrm{E}$ disorders. Expert Rev Hematol 3: 103-117.

5. Olivieri NF, 1999. The beta-thalassemias. N Engl J Med 341: 99-109.

6. Tyan PI, Radwan AH, Eid A, Haddad AG, Wehbe D, Taher AT, 2014. Novel approach to reactive oxygen species in nontransfusion-dependent thalassemia. Biomed Res Int 2014: 350432.

7. Ahmed S, Saleem M, Modell B, Petrou M, 2002. Screening extended families for genetic hemoglobin disorders in Pakistan. N Engl J Med 347: 1162-1168.

8. Biswas A, Sarkar K, Firdaus R, Saha K, Gupta D, Ghosh M, Chowdhury P, Bhattacharyya D, Bhattacharyya M, Sadhukhan PC, 2016. Prevalence of anti-HCV, HBsAg, HIV among multitransfused thalassemic individuals and their socio-economic background in eastern India. Asian J Pharm Clin Res 9: 314-318.

9. Muncie JH, Campbell JJ, 2009. Alpha and beta thalassemia. Am Fam Physician 80: 339-344.

10. WHO, 2017. Viral Hepatitis: A Hidden Killer Gains Visibility. Geneva, Switzerland: World Health Organization. Available at: https://www.who.int/publications/10-year-review/hepatitis/en/. Accessed September 1, 2020.

11. WHO, 2019. Combating Hepatitis $B$ and $C$ to Reach Elimination by 2030 Advocacy Brief. Geneva, Switzerland: World Health Organization. Available at: https://www.who.int/hepatitis/publications/hepelimination-by-2030-brief/en/. Accessed September 1, 2020.

12. Waheed $Y$, Siddiq M, 2018. Elimination of hepatitis from Pakistan by 2030: is it possible? Hepatoma Res 4: 45.

13. Ali M, Idrees M, Ali L, Hussain A, Ur Rehman I, Saleem S, Afzal S, Butt S, 2011. Hepatitis B virus in Pakistan: a systematic review of prevalence, risk factors, awareness status and genotypes. Virol J 8: 102.

14. Khokhar N, Gill ML, Malik GJ, 2004. General seroprevalence of hepatitis $\mathrm{C}$ and hepatitis $\mathrm{B}$ virus infections in population. $J$ Coll Physicians Surg Pak 14: 534-536.

15. Polaris-Observatory-Collaborators, 2018. Global prevalence, treatment, and prevention of hepatitis $B$ virus infection in 2016: a modelling study. Lancet Gastroenterol Hepatol 3: 383-403.

16. Polaris-Observatory-HCV-Collaborators, 2017. Global prevalence and genotype distribution of hepatitis $C$ virus infection in 2015: a modelling study. Lancet Gastroenterol Hepatol 2: 161-176.
17. Waheed $Y$, Siddiq M, Jamil Z, Najmi MH, 2018. Hepatitis elimination by 2030: progress and challenges. World $J$ Gastroenterol 24: 4959-4961.

18. Waheed Y, Shafi T, Safi SZ, Qadri I, 2009. Hepatitis C virus in Pakistan: a systematic review of prevalence, genotypes and risk factors. World J Gastroenterol 15: 5647-5653.

19. Ali SA, Donahue RM, Qureshi H, Vermund SH, 2009. Hepatitis B and hepatitis $\mathrm{C}$ in Pakistan: prevalence and risk factors. Int $J$ Infect Dis 13: 9-19.

20. Mir F et al., 2020. HIV infection predominantly affecting children in Sindh, Pakistan, 2019: a cross-sectional study of an outbreak. Lancet Infect Dis 20: 362-370.

21. Ricerca BM, Di Girolamo A, Rund D, 2009. Infections in thalassemia and hemoglobinopathies: focus on therapy-related complications. Mediterr J Hematol Infec Dis 1: e2009028.

22. Samimi-Rad K, Asgari F, Nasiritoosi M, Esteghamati A, Azarkeyvan A, Eslami SM, Zamani F, Magnius L, Alavian SM, Norder H, 2013. Patient-to-patient transmission of hepatitis C at Iranian thalassemia centers shown by genetic characterization of viral strains. Hepat Mon 13: e7699.

23. Alam MM, Zaidi SZ, Malik SA, Naeem A, Shaukat S, Sharif S, Angez M, Khan A, Butt JA, 2007. Serology based disease status of Pakistani population infected with Hepatitis $B$ virus. BMC Infect Dis 7: 64.

24. Rehman A, Mazhar A, Sheikh MA, Naeem MM, Bhatti IA, 2012. Hepatitis $B$ surface antigen carrier rate in unvaccinated and vaccinated children with thalassaemia major at Bahawal Victoria Hospital, Bahawalpur, Pakistan. East Mediterr Health J 18: 378-381.

25. Mahmud S, Al Kanaani Z, Abu-Raddad LJ, 2019. Characterization of the hepatitis C virus epidemic in Pakistan. BMC Infect Dis 19: 809.

26. Behzadifar M, Gorji HA, Bragazzi NL, 2018. The prevalence of hepatitis $C$ virus infection in thalassemia patients in Iran from 2000 to 2017: a systematic review and meta-analysis. Arch Virol 163: 1131-1140.

27. Kadhim KA, Baldawi KH, Lami FH, 2017. Prevalence, incidence, trend, and complications of thalassemia in Iraq. Hemoglobin 41: 164-168.

28. Shyamala V, 2014. Transfusion transmitted infections in thalassaemics: need for reappraisal of blood screening strategy in India. Transfus Med 24: 79-88.

29. Ahmed Kiani R, Anwar M, Waheed U, Asad MJ, Abbasi S, Abbas Zaheer $\mathrm{H}, 2016$. Epidemiology of transfusion transmitted infection among patients with $\beta$-thalassaemia major in Pakistan. J Blood Transfusion 2016: 8135649.

30. Twagirumugabe T, Swaibu G, Bergstrom T, Walker TD, Gahutu $\mathrm{JB}$, Norder $\mathrm{H}, 2017$. Low prevalence of hepatitis $\mathrm{C}$ virus RNA in blood donors with anti-hepatitis $\mathrm{C}$ virus reactivity in Rwanda. Transfusion 57: 2420-2432.

31. Felsenstein J, 2008. Comparative methods with sampling error and within-species variation: contrasts revisited and revised. Am Nat 171: 713-725.

32. Ghosh $S$ et al., 2013. New HBV subgenotype D9, a novel D/C recombinant, identified in patients with chronic $\mathrm{HBeAg}$ negative infection in Eastern India. J Viral Hepat 20: 209-218.

33. Chauhan R, Kazim SN, Kumar M, Bhattacharjee J, Krishnamoorthy N, Sarin SK, 2008. Identification and characterization of genotype $A$ and $D$ recombinant hepatitis $B$ virus from Indian chronic HBV isolates. World $J$ Gastroenterol 14: 6228-6236.

34. Saeed U, Waheed Y, Ashraf M, Waheed U, Anjum S, Afzal MS, 2015. Estimation of hepatitis B virus, hepatitis $C$ virus, and different clinical parameters in the thalassemic population of capital twin cities of Pakistan. Virology (Auckl) 6: 11-16.

35. Yasmeen $\mathrm{H}$, Hasnain S, 2019. Epidemiology and risk factors of transfusion transmitted infections in thalassemia major: a multicenter study in Pakistan. Hematol Transfus Cell Ther 41: 316-323.

36. Shah T, Hussain W, Ali N, Sardar S, Ishaq M, UrRahman M, Ding L, Qayyum S, Khan I, 2019. Frequency distribution and risk factors of hepatitis B virus and hepatitis $C$ virus infections among thalassemia patients: a regional study. Eur $J$ Gastroenterol Hepatol 31: 248-252.

37. Khan A, Tareen AM, Ikram A, Rahman H, Wadood A, Qasim M, Khan K, 2013. Prevalence of HCV among the young male blood donors of Quetta region of Balochistan, Pakistan. Virol J 10: 83. 
38. Gower E, Estes C, Blach S, Razavi-Shearer K, Razavi H, 2014. Global epidemiology and genotype distribution of the hepatitis C virus infection. J Hepatol 61: S45-S57.

39. Bhatti FA, Amin M, Saleem M, 1995. Prevalence of antibody to hepatitis $C$ virus in Pakistani thalassaemics by particle agglutination test utilizing C-200 and C22-3 vital antigen coated particles. J Pak Med Assoc 45: 269-270.

40. Ehsan H, Wahab A, Anwer F, Iftikhar R, Yousaf MN, 2020. Prevalence of transfusion transmissible infections in betathalassemia major patients in Pakistan: a systematic review. Cureus 12: e10070.

41. Khan AA, Khan A, 2010. The HIV epidemic in Pakistan. J Pak Med Assoc 60: 300-307.
42. Khaliq S, Raza SM, 2018. Current status of direct acting antiviral agents against hepatitis $\mathrm{C}$ virus infection in Pakistan. Medicina (Kaunas) 54: 80.

43. Ebrahim $S$ et al., 2019. Knowledge and Beliefs regarding thalassemia in an urban population. Cureus 11: e5268.

44. Yasmeen $\mathrm{H}$, Hasnain S, 2018. Quality of life of Pakistani children with beta-thalassemia major. Hemoglobin 42: 320-325.

45. Al-Moshary M, Al-Mussaed E, Khan A, 2019. Prevalence of transfusion transmitted infections and the quality of life in $\beta$-thalassemia major patients. Cureus 11: e6129.

46. Thiyagarajan A, Bhattacharya S, Sharma N, Srivastava A, Dhar DK, 2019. Need for a universal thalassemia screening programme in India? A public health perspective. J Fam Med Prim Care 8: 1528-1532. 